\title{
The importance of the mental foramen location detection by using different radiographic technique: Mini review
}

\author{
Mohammed Jasim Al-Juboori ${ }^{1,}$, , Chua Miao Hua ${ }^{2}$, Kuo Yuet Yuen² \\ ${ }^{1}$ Lecturer in oral surgery department/ Dental Faculty, MAHSA University, level 4, block E, pusat bandar damansara, Kuala Lumpur, \\ Malaysia \\ ${ }^{2}$ Dental Faculty, MAHSA University, level 4, block E, pusat bandar damansara, Kuala Lumpur, Malaysia \\ Email address: \\ doctor_mohamed_2006@yahoo.com(M. J. Al-Juboori)
}

\section{To cite this article:}

Mohammed Jasim Al-Juboori, Chua Miao Hua, Kuo Yuet Yuen. The Importance of the Mental Foramen Location Detection by Using Different Radiographic Technique: Mini Review. International Journal of Medical Imaging. Vol. 2, No. 3, 2014, pp. 63-68.

doi: 10.11648/j.ijmi.20140203.14

\begin{abstract}
This review gives detail information about the mental foramen location, shape, size and numbers and its variation between races. Studies have shown that there are variations in the position of mental foramen in different populations. It may lie between the apices of premolars, below the apex of first or second premolars. This variations mandate accurate detection of foramen during examination and treatment plan stage. Foramen detection usually done by 2 dimension radiograph, with high chances of error. Three dimension radiograph provide the operator more precise location and dimension of the foramen that decrease the chances of the mental nerve damaging during the surgery.
\end{abstract}

Keywords: Mental Foramen, Nerve Damage, Radiograph, Dental Implant, Oral Surgery

\section{Introduction}

Knowing the location of the mental foramen is very important when considering placing implants or any other surgical procedure in the foraminal region. The complications, such as altered sensation, numbness and pain can be avoided if the mental foramen is located and evaluated. ${ }^{1}$ There are variations in the location, the number of foramina, and the possibility that an anterior loop may be present mesial to the mental foramen in different populations. This article reviews the literature with respect to the mental foramen and determines the safety zone prior to preparing an osteotomy for implant placement in this region.

\section{Mental Foramen}

\subsection{Shape}

According to Mbajiorgu et al. ${ }^{2}$, there are different shapes of the mental foramen be found in the mandibles of Zimbabwean subjects: round in 14 of 32 mandibles (43.8\%) and oval in 18 of 32 jaws (56.3\%). Meanwhile, Grershenson A. et al. ${ }^{3}$ reported that it was round in $34.5 \%$ of mandibles and oval in $65.5 \%$.

\subsection{Size}

Neiva et al. ${ }^{4}$ stated that the morphometric skull analyses revealed the mean height of the mental foramen was $3.47 \mathrm{~mm}$ (range: 2.5 to $5.5 \mathrm{~mm}$ ) and the average width was $3.59 \mathrm{~mm}$ (range: 2 to $5.5 \mathrm{~mm}$ ). Others reported that the mean diameter of the foramen was $3.5 \mathrm{~mm}^{5}$ and $5 \mathrm{~mm}$ wide. ${ }^{6}$

\subsubsection{Location}

According to textbooks of anatomy, the mental foramen is located below the interval between the premolar, or the second premolar, from which emerge the mental nerve and vessels. $^{34}$ However, there are anatomical variations concerning the mental foramen's location. ${ }^{7,8}$ It is usually found more coronal than the mandibular canal. ${ }^{9,10}$ Neiva et al. ${ }^{4}$ reported the foramen was $27.6 \mathrm{~mm}$ ( range: 22 to $31 \mathrm{~mm}$ ) from the midline and $12 \mathrm{~mm}$ (range: 9 to $15 \mathrm{~mm}$ ) from the most apical portion of the lower cortex of the mandible. Meanwhile, Agthong et al. ${ }^{11}$ stated that the foramen was 28 $\mathrm{mm}$ from the midline of the mandible and 14 to $15 \mathrm{~mm}$ from the inferior border of the mandible. Other investigators noted that the foramen was usually found halfway between the crest of bone and the inferior border of the mandible. ${ }^{12}$

Table $1^{4,10,13-16,27-32}$ lists studies that addressed the mental foramen's location in the horizontal plane. Usually, it is 
located by the apex of the second mandibular premolar or between the apices of the premolars. However, there are some minor differences among the races. For example, Wang et al. ${ }^{13}$ stated that the mental foramen in the Chinese population is usually located apical to the second premolar, whereas in Caucasian subjects, according to Fishel et al. ${ }^{10}$ and Neiva et al. ${ }^{4}$, it is usually found between the premolars. Atypically, it can be found anteriorly by the canine or posteriorly by the first molar. ${ }^{14-16,27,29,31-32}$

Table 1. Locations of mental foramen that detected from different study in different races and techniques

\begin{tabular}{|c|c|c|c|c|c|c|}
\hline Study & Population & $\mathbf{N}$ & $\begin{array}{l}\text { Horizontal Plane } \\
\text { Apical to second } \\
\text { premolar }\end{array}$ & $\begin{array}{l}\text { Between apices } \\
\text { of premolars }\end{array}$ & Other locations & Vertical Plane \\
\hline $\begin{array}{l}\text { Fishel et al. } \\
(1976)^{10}\end{array}$ & Caucasian & 1000 & 18.9 & 70.4 & $\begin{array}{l}\text { Apex first premolar: } 3.3 \\
\text { Mesial to first premolar: } 1.5 \\
\text { Between premolar/molar: } \\
6.6 \\
\text { By the molar: } 1\end{array}$ & $\begin{array}{l}\text { Superior to the level of the } \\
\text { apices of the premolars }\end{array}$ \\
\hline $\begin{array}{l}\text { Wang et al. } \\
(1986)^{13}\end{array}$ & Chinese & 100 & 59 & 21 & $\begin{array}{l}\text { Between premolars/ molars: } \\
19 \\
\text { By the molar: } 1\end{array}$ & $\begin{array}{l}\text { Distance between superior } \\
\text { border of the MF and the } \\
\text { bottom of the lower second } \\
\text { premolar socket: } 2.50 \mathrm{~mm}\end{array}$ \\
\hline $\begin{array}{l}\text { Kekere - Ekun } \\
(1989)^{15}\end{array}$ & Nigerian & 604 & 55.63 & 26.99 & $\begin{array}{l}\text { Mesial to first premolar: } \\
0.17 \\
\text { Apex first premolar: } 1.66 \\
\text { Between premolar/ molars: } \\
12.3 \\
\text { By the molar: } 3.3\end{array}$ & Not measured \\
\hline $\begin{array}{l}\text { Shankland } \\
(1994)^{27}\end{array}$ & $\begin{array}{l}\text { Asian } \\
\text { Indians }\end{array}$ & 138 & 75.4 & 5.8 & $\begin{array}{l}\text { Between premolar/ molars: } \\
14.5 \\
\text { By the molar: } 4.3\end{array}$ & Not measured \\
\hline $\begin{array}{l}\text { Al Jasser and } \\
\text { Nwoku }(1998)^{28}\end{array}$ & Saudi & 414 & 45.3 & 42.7 & Not measured & Not measured \\
\hline $\begin{array}{l}\text { Ngeow and } \\
\text { Yuzawati }(2003)^{14}\end{array}$ & Malay & 169 & 69.2 & 19.6 & $\begin{array}{l}\text { Apex first premolar: } 3.4 \\
\text { Between premolar/ molar: } \\
6.6 \\
\text { By the molar: } 1\end{array}$ & Not measured \\
\hline $\begin{array}{l}\text { Neiva et al. } \\
(2004)^{4}\end{array}$ & Caucasian & 22 & 42 & 58 & Not measured & $\begin{array}{l}\text { Distance between MF and } \\
\text { CEJ of teeth: } 15.52+/-2.37 \\
\mathrm{~mm}\end{array}$ \\
\hline $\begin{array}{l}\text { Apinhasmit et al. } \\
(2006)^{29}\end{array}$ & Thai & 106 & 56.9 & 28.7 & $\begin{array}{l}\text { Between premolar/ molar: } \\
10.2 \\
\text { Apex first premolar: } 3 \\
\text { By the molar: } 1.2\end{array}$ & Not measured \\
\hline Kim et al. $(2006)^{30}$ & Korean & 72 & 64.3 & 26.8 & Apex first premolar: 8.9 & $\begin{array}{l}\text { Distance between the cusp tip } \\
\text { and the superior border of the } \\
\text { mental foramen: } 23.42 \mathrm{~mm}\end{array}$ \\
\hline Fabian $(2007)^{31}$ & Tanzanian & 100 & 45 & 12 & $\begin{array}{l}\text { Between premolar/ molar: } \\
35 \\
\text { By the molar: } 8\end{array}$ & Not measured \\
\hline $\begin{array}{l}\text { Haghanifar and } \\
\text { Rokouei }(2009)^{32}\end{array}$ & Iranian & 400 & 46 & 47.2 & $\begin{array}{l}\text { Between premolar/molar: } \\
5.3 \\
\text { By the molar: } 1.5\end{array}$ & Not measured \\
\hline
\end{tabular}

Fishel et al. ${ }^{10}(\mathrm{~N}=936$ full-mouth series) commented that the mental foramen's location in the vertical plane (occluso-apically) for the first and second premolars: $38.6 \%$ coronal to the apex of the first premolars, $15.4 \%$ at the apex of the first premolars, and $46.0 \%$ apical to the apex of the first premolars; whereas for the second bicuspids, $24.5 \%$ coronal to the apex, $13.9 \%$ at the apex, and $61.6 \%$ apical to the apex. It can be concluded that the foramen's location is not constant in the horizontal or vertical planes. ${ }^{1}$

It can be seen that the mental foramen is closer to the alveolar crest after the extraction of teeth and resorption of alveolar bone. In some extreme situations, the mental foramen and mandibular canal can be adjacent to the crest of the alveolar ridge. Hence, using alveolar crest bone as a landmark is not stable because different levels of crestal bone loss existed.

\subsubsection{Number of Foramina}

There may be more than one mental foramen present. ${ }^{7,8}$ Sawyer et al. ${ }^{8}$ assessed the frequency of accessory mental foramina in skulls in 4 population groups: American Whites $=1.4 \%$; Asian Indians = 1.5\%; African Americans = 5.7\%; and pre-Columbian Nazca Indians $=9.0 \%$. Some studies found that there were two mental foramina in $1.8 \%(\mathrm{~N}=110)$ of examined Asian skulls ${ }^{11}$ and in $10 \%(\mathrm{~N}=50)$ of examined cadavers. ${ }^{33}$ In contrast, de Freitas et al. ${ }^{24}$ found no mental foramen in some skulls (among 1,435 dry human mandibles, 
the foramen was absent twice on the right side [0.06\%] and once on the left side [0.03\%]). It can be concluded that there is a variety of patterns occurs, and it should not be assumed that there is only one mental foramen on each side. ${ }^{1}$

\subsubsection{Path of Emergence of Mental Foramen}

According to Solar et al. ${ }^{6}$, the mental canal (the anterior opening of the mandibular canal) traverses cranially at an angle of inclination ranging from $11^{\circ}$ to $77^{\circ}$. The average gradient was $50^{\circ}$ in 37 specimens and 22 had an anterior loop. Kieser et al. ${ }^{25}$ classified the path of emergence of mental foramen into posterior, anterior, right-angled or multiple. They investigated the path of emergence of the mental canal in 117 Negro skulls (53 males), 114 Caucasoid skulls (62 males) and 100 pre-contact Maori skulls (70 males). Among all the Caucasoid and Maori skulls, the most common pattern of emergence was a posterior direction (86.7\% of Caucasoid males, $90.2 \%$ of Caucasoid females; $85.5 \%$ of Maori males, and $93.1 \%$ of Maori females). While for the Black population, the most common pattern of path of emergence was the right-angled one, which was $45.8 \%$ of males, $45.0 \%$ of females. In Fabian's study on measurements of 100 Tanzanian mandibles ${ }^{31}$, he concluded that the direction of mental foramen opening was superiorly in $44 \%$, posterosuperiorly in $40 \%$, labially in $10 \%$; mesially (anteriorly) in 3\%), and posteriorly in 3\% of cases. (Figure 1). To create multileveled equations, it may be necessary to treat the equation as a graphic and insert it into the text after your paper is styled.

\section{Detection of Mental Foramen on Radiograph}

The ideal imaging technique for dental implant care should have several important characteristics such as, the ability to visualize the implant site in the mesiodistal, faciolingual and superioinferior dimensions; the ability to allow reliable, accurate measurements; a capacity to evaluate trabecular bone density and cortical thickness; a capacity to correlate the imaged site with the clinical site; reasonable access and cost to the patient; and minimal radiation risk.

The radiographic techniques that can be used to access the location of mental foramen are panoramic radiography, intraoral radiography, cephalometric radiography, conventional tomography as well as cone-beam and multidetector computed tomography. ${ }^{35}$

\subsection{Panoramic Radiography}

Philips et al. found mental foramen on $75 \%(\mathrm{~N}=75)$ of periapical films ${ }^{40}$, whereas Fishel et al. found mental foramen on $46.8 \%(\mathrm{~N}=1000)$ of periapical films in their study. ${ }^{10}$ In order to enhance the detection of foramen, it was suggested that a vertical bitewing and a panoramic film be taken in conjunction with a horizontal periapical film. ${ }^{42}$ Ngeow WC also suggested that 2 periapical radiographs should be obtained at different angles (parallax technique), to ascertain the exact relationship of the premolars to the mental foramen. ${ }^{43}$ Al-juboori et $\mathrm{al}^{44}$, conduct a study among Malaysian population to detect the mental foramen location by using panoramic radiograph, the study shows the feasibility of using panoramic radiograph in detection the location of the mental foramen among different races.

\subsection{Digital Radiography}

Digital radiography has more advantages than conventional plain film radiography, including speed, convenience, lack of darkroom procedures, computer image improvement, less environmental contamination and better patient education. It also imposes lower radiation exposure dose to the patient ${ }^{45,46}$. Studies have found that digital radiography has a $50-80 \%$ decrease in exposure dose compared with conventional plain film imaging.

However, on average, the total amount of decrease in exposure dose is $25 \%$, as clinicians tend to repeat more radiographs when using the digital radiograph ${ }^{47,48}$. Parissis et al, also found that digitized radiographs has higher density than the conventional radiographs, moreover, they demonstrated a narrower density range. The resolution between the digitized image and the film-based radiographs has found to be the same. ${ }^{45}$

\subsection{Computed Tomography (CT)}

Computed tomogram enables the mandible to be visualized in three dimensions. ${ }^{49-55}$ The mandibular canal and its surrounding bone can be appreciated in three dimensions. By using computed tomogram, the clinicians will be able to know the bone density, buccolingual position of the mandibular canal, height of the bone. ${ }^{49-58}$ The accuracy of computed tomography was within $0.5 \mathrm{~mm}$ of the caliper measurement in every reading taken. There was no distortion of the computerized tomographic measurements in eight out of the twelve readings. According to Sonick et $\mathrm{al}^{59}$, the following average linear errors occurred during routine bone assessment $(\mathrm{N}=12)$ : panoramic films: $24 \%$ (mean: $3 \mathrm{~mm}$; range: $0.5-7.5 \mathrm{~mm}$ ); periapical films: $14 \%$ (mean: $1.9 \mathrm{~mm}$; range: 0.0 to $5.0 \mathrm{~mm}$ ); and computerized tomography scans: $1.8 \%$ (mean: $0.2 \mathrm{~mm}$; range: 0.0 to $0.5 \mathrm{~mm}){ }^{59}$

\section{Mental Nerve Damage Due to Miss Diagnosed Mental Foramen during Dental Implant Treatment}

According to Sharawy et al., nerve damage can result from the nerve being stretched, compressed, and partially or totally transected. ${ }^{60}$ Parasthesia (numb feeling), hypoesthesia (reduced feeling), hyperesthesia (increased sensitivity), dysthesia (painful sensation), or anesthesia (complete loss of feeling) of the teeth, the lower lip, or surrounding skin and mucosa may be encountered during an 
osteotomy. ${ }^{60}$ It is not surprising that venous or arterial bleeding can also occur. Other terms used to describe nerve injuries are: ${ }^{61}$

Neurapraxia: The nerve has been stretched or undergone blunt trauma. No loss of continuity of the nerve occurs. The parasthesia will subside and feelings will be returned in days to weeks.

Axonotmesis: There is nerve damage, but the damage is not severe. Feelings will be returned within 2 to 6 months.

Neurotmesis: There is severe nerve damage. It is a poor prognosis for resolution of paresthesia.

Reasons like osteotomy locations, manner of surgery, study design, sensitivity of assessment techniques, selection of outcome variables, and terminology employed to explain sensory disturbances determine the prevalence of sensory alterations. ${ }^{62}$ Walton ${ }^{63}$ reported that $1 \%$ of the patients experienced sensory alterations 1 year after therapy, whereas Bartling et al. ${ }^{64}$ noted no permanent alterations of sensation 4 months post therapy $(\mathrm{N}=94)$. Some investigators found transient altered lip sensations after implant placement in the anterior mandible: $8.5 \%(\mathrm{~N}=94)^{64}, 11 \%(\mathrm{~N}=110)^{41}$, and $24 \%(\mathrm{~N}=75)$ of patients. ${ }^{63}$ In another study, $7 \%(\mathrm{~N}=110)$ of the patients noted sensory disturbance 16 months after the treatment. ${ }^{41}$ Although the mental foramen was exposed as part of the surgical procedure and placement of implants at least $3 \mathrm{~mm}$ in front of the mental foramen, this incident still occurred. Due to these issues, patients must be forewarned of these possible complications prior to implant surgery. Besides, Flanagan ${ }^{37}$ reported that there was delayed onset of altered sensation of the mental nerve after surgery. According to him, it might be due to the remote bone compression which causing his patients to experience transient altered sensation. It was not due to the direct injury induced by the twist drill. Flanagan ${ }^{37}$ believed that the implant, which compresses the cancellous bone may in turn presses on the nerve, resulting in nerve dysfunction. Bone compression occurs because the implant used is usually $0.5 \mathrm{~mm}$ wider than the osteotomy, and because of this, the force may be transferred to the nerve.

Table 2. Appearance of mental foramina on panoramic radiographs. Percentage of occurrence from Yosue et al study $y^{38}$

\begin{tabular}{lll}
\hline Category & Radiographic Appearance & $\begin{array}{l}\text { Incidence } \\
\text { (N=297) }\end{array}$ \\
\hline Continuous & $\begin{array}{l}\text { Foramen has continuity with the } \\
\text { mandibular canal }\end{array}$ & $21 \%$ \\
Separated & $\begin{array}{l}\text { Foramen distinctly separated from the } \\
\text { canal }\end{array}$ & $43 \%$ \\
Diffuse & Foramen has indistinct border & $24 \%$ \\
\hline Unidentified & Foramen cannot be identified & $12 \%$ \\
\hline
\end{tabular}

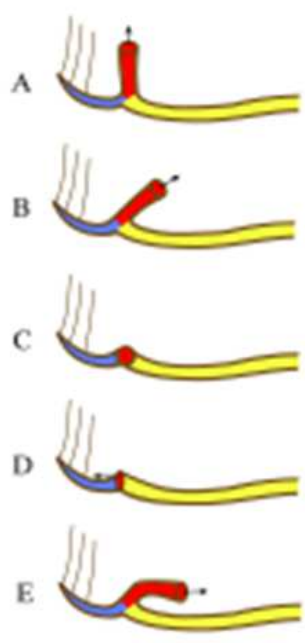

Figure 1. Emergence patterns of the mental canal and mental foramen opening. Colours: blue $=$ mandibular incisive canal, red $=$ mental canal 9 the anterior opening of the mandibular canal), yellow = mandibular canal, $\mathrm{A}=$ superiorly, $\mathrm{B}=$ posterosuperiorly, $\mathrm{C}=$ labially, $\mathrm{D}=$ mesially (anteriorly), $\mathrm{E}$ $=$ posteriorly

\section{Conclusion}

From this mini review we can conclude that 3 dimensional imaging which is presented by computerized tomography is mandatory when dental implant or oral surgical procedure conducted in the mental foramen area, this will prevent neural complication and patient morbidity

\section{Acknowledgements}

Acknowledge goes to Mr. Mohammed Zaki Noor Al-Hashimi/ biostatistics lecturer in MAHSA University, for his great support and effort

\section{References}

[1] Gary Greenstein and Dennis Tarnow. The mental foramen and nerve: Clinical and anatomical factors related to dental Implant Placement: A Literature Review. Journal of Periodontology 2006; 77: 1933-1943

[2] Mbajiorgu EF, Mawera G, Asala SA, et al. Position of the mental foramen in adult black Zimbabwean mandibles: A clinical anatomical study. Cent Afr J Med 1998; 44: 24-30

[3] Gershenson A, Nathan H, Luchansky E. Mental foramen and mental nerve: Changes with age. Acta Anat (Basel) 1986; 126:21-28.

[4] Neive RF, Gapski R, Wang HL. Morphometric analysis of implant-related anatomy in Caucasian skulls. J periodontal 2004; 75:1061-1067.

[5] Yosue T, Brooks SL. The appearance of mental foramina on panoramic radiographs. I. Evaluation of patients. Oral Surg Oral Med Oral Pathol 1989; 68:360-364.

[6] Solar P, Ulm C, Frey G, et al. A classification of intraosseous paths of the mental nerve. Int J Oral Maxillofac Implants 1994; 9:339-344. 
[7] Shankland WE. The position of the mental foramen in Asian Indians. J Oral Implantol 1994; 20:118-123.

[8] Sawyer DR, Kiely ML, Pyle MA. The frequency of accessory mental foramina in four ethnic groups. Arch Oral Biol 1998; 43: 417-420.

[9] Bavitz JB, Harn SD, Hansen CA, Lang M. An anatomical study of mental neurovascular bundle-implant relationships. Int J Oral Maxillofac Implants 1993; 8: 563-567.

[10] Fishel D, Buchner A, Hershkowith A, et al. Roentgenologic study of the mental foramen. Oral Surg Oral Med Oral Pathol 1976; 41: 682-686.

[11] Agthong S, Huanmanop T, Chentanex V. Anatomical variations of the supraorbital, infraorbital, and mental foramina related to gender and side. J Oral Maxillofac Surg 2005; 63: 800-804.

[12] Mraiwa N, Jacobs R, van Steenberghe D, et al. Clinical assessment and surgical implications of anatomic challenges in the anterior mandible. Clin Implant Dent Relat Res 2003; 5: 219-225.

[13] Wang TM, Shih C, Liu JC, et al. A clinical and anatomical study of the location of the mental foramen in adult Chinese mandibles. Acta Anat (Basel) 1986; 126: 29-33.

[14] Ngeow WC, Yuzawati Y. The location of the mental foramen in a selected Malay population. J Oral Sci 2003; 45: 171-175.

[15] Kekere-Ekun TA. Antero-posterior location of the mental foramen in Nigerians. Afr Dent J 1989; 3: 2-8.

[16] Bergman RA, Afifi AK, Miyauchi R. mental foramen. In: Illustrated Encyclopedia of Huaman Anatomic Variation: Opus V: Skeletal Systems. Available at: http:// www.anatomyatlases.org/Anatomic

Variants/SkeletalSystem/Images/127.shtml. Accessed June 21, 2006.

[17] Ulm CW, Solar P, Blahout R, et al. Location of the mandibular canal within the atrophic mandible. Br J Oral Maxillofac Surg 1993; 31: 370-375.

[18] Block MS. Color Atlas of Dental Implant Surgery. Philadelphia: W.B. Saunders; 2001; 9.

[19] Morrison A, Chiarot M, Kirby S. Mental nerve function after inferior alveolar nerve transposition for placement of dental implants. J Can Dent Assoc 2002; 68: 46-50.

[20] Babbush CA. Transpositioning and repositioning the inferior alveolar and mental nerves in conjunction with endosteal implant reconstruction. Periodontol 2000; 17: 183-190.

[21] Hori M, Sato T, Kaneko K, et al. Neurosensory function and implant survival rate following implant placement with nerve transpositioning: A case study. J Oral Sci 2001; 43: 139-144.

[22] Nocini PF, De Santis D, Fracasso E, et al. Clinical and electrophysiological assessment of inferior alveolar nerve function after lateral nerve transposition. Clin Oral Implants Res 1999; 10: 120-130.

[23] Ellies LG, Smiler DG, Quadland MW, et al. Inferior alveolar nerve repositioning: Is there cause for concern? Dent Implantol Update 1995; 6: 37-39.

[24] De Freitas V, Madeira MC, Toledo Filho JL, et al. Absence of the mental foramen in dry human mandibles. Acta Anat
(Basel) 1979; 104: 3533-355.

[25] Kieser J, Kuzmanovic D, Payne A, et al. Patterns of emergence of the human mental nerve. Arch Oral Biol 2002; $51: 14-16$.

[26] Oguz O, Bozkir MG. Evaluation of location of mandibular and mental foramina in dry, young, adult human male, dentulous mandibles. West Indian Med J 2002; 51: 14-16.

[27] Shankland WE. The position of the mental foramen in Asian Indians. J Oral Implantol, 1994; 20: 118-123.

[28] Al-Jasser, Nwoku AL. Radiographic study of the mental foramen in a selected Saudi population. Dentomaxillofac Radiol., 1998; 27: 341-343.

[29] Apinhasmit W, Chompoopong S, Methathrathip D, et al. Supraorbital Notch/Foramen, Infraorbital Foramen and Mental Foramen in Thais: anthropometric measurements and surgical relevance. J Med Assoc Thai., 2006; 89: 675-682

[30] Kim IS, Kim SG, Kim YK, et al. Position of the mental foramen in a Korean population: a clinical and radiographic study. Implant Dent. 2006 ; 15:404-11

[31] Fabian FM. Position, shape and direction of opening of the mental foramen in dry mandibles of Tanzanian adult black males. Ital J Anat Embryol. 2007; 112:169-77

[32] Sina Haghanifar, Mehrak Rokouei Radiographic evaluation of the mental foramen in a selected Iranian population. Indian J Dent Res, 2009; 20,

[33] Mraiwa N, Jacobs R, Moerman P, et al. Presence and course of the incisive canal in the human mandibular interforaminal region: Two-dimensional imaging versus anatomical observations. Surg Radiol Anat 2003; 25: 416-423.

[34] Williams PL, Warwick R, Dyson M, banister LH Grays Anatomy. 37th ed. Churchill Livingstone, London, UK, 1989 pp. 367

[35] Stuart C. White, Michael J. Pharoah. Oral radiology: Principles and Interpretation. 6th ed. Mosby, 2009; pp597.

[36] Jacobs R, Mraiwa N, Van Steenberghe D, et al, Quirynen M. Appearance of the mandibular incisive canal on panoramic radiographs. Surg Radiol Anat 2004;26:329-333.

[37] Flanagan d. Delayed onset of altered sensation following dental implant placement and mental block local anesthesia: A case report. Implant Dent 2002; 11:324-330

[38] Yosue T, Brooks SL. The appearance of mental foramina on panoramic and periapical radiographs. II. Experimental evaluation. Oral Surg Oral Med Oral Pathol 1989; 68:488-92.

[39] Dharmar S. Locating the mandibular canal in panoramic radiographs. Int J Oral Maxillofac Implants 1997;12:113-117

[40] Phillips JL,Weller RN, Kulild JC. The mental foramen: 1. Size, orientation, and positional relationship to the mandibular second premolar. J Endod 1990; 16:221-223.

[41] Wismeijer D, van Waas MA, Vermeeren JI, et al. Patients' perception of sensory disturbances of the mental nerve before and after implant surgery: A prospective study of 110 patients. Br J Oral Maxillofac Surg 1997; 35: 254-259

[42] Moiseiwitsch JR. Avoiding the mental foramen during periapical surgery. J Endod 1995; 21:340-342. 
[43] Ngeow WC. Is there a "safety zone" in the mandibular premolar region where damage to the mental nerve can be avoided if periapical extrusion occurs? J Can Dent Assoc 2010; 76: a61.

[44] Al-Juboori MJ, Al-Wakeel HA, yun CM, et al. Location of mental foramen among Malaysia populations: Retrospective study by using orthopantomogram. World J. Med. Med. Sci. Res $2013 ; 1: 85-90$

[45] Parissis N, kondylidou-Sidira A, Tsirlis A, et al. Conventional radiographs vs digitized radiographs: image quality assessment. Dentomaxillofac Radiol 2005; 34: 353-6.

[46] Molander B, Grondahl HG, Ekestubbe A. Quality of film-based and digital panoramic radiography. Dentomaxillofac Radiol 2004; 33: 32-36.

[47] Gijbels F, Jacobs R, Bogaerts R, et al, Dosimetry of digital panoramic imaging. Part I: patient exposure. Dentomaxillofac Radiol 2005; 34: 145-149.

[48] Berkhout WER, Sanderink GCH, Van der Stelt PF. Does digital radiography increase the number of intraoral radiographs? A questionnaire study of Dutch dental practices. Dentomaxillofac Radiol 2003; 32: 124-127.

[49] Schwarz MS, Rothman SLG, Rhodes ML, et al. Computerized tomography: Part I. Preoperative assessment of the mandible for endosseous implants surgery. Int J Oral Maxillofac Implants 1987; 2:137-141.

[50] Rothman SLG, Chafetz N, Rhodes ML, Schwarz MS. CT in the preoperative assessment of the mandible and maxilla for endosseous implant surgery. Radiology 1988; 168:171-175.

[51] McGivney GP, Haughton V, Strandt JA, et al. A comparison of computer-assisted tomography and data-gathering modalities in prosthodontics. Int J Oral Maxillofac Implants 1986; 1:55-68.

[52] Schwarz MS, Rothman SLG, Chafetz N, et al. Computed tomography in dental implantation surgery. Dent Clin N Am $1989 ; 33: 555-597$.

[53] Wishan MS, Bahat O, Krane M. Computed tomography as an adjunct in dental implant surgery. Int $\mathrm{J}$ Periodont Rest Dent .1988; 8:30-47.

[54] Abrahams JJ, Levine B. Expanded application of DentaScan (multiplanar computerized tomography of the mandible and maxilla). Int J Periodont Rest Dent 1990; 10:465-471.

[55] Abrahams JJ. CT Assessment of dental implant planning. Oral Maxillofac Surg Clin N Am 1992; 4:1-18.

[56] Jaffin RA, Berman CL. The excessive loss of Brånemark fixtures in type IV bone: A 5 year analysis. J Periodontol $1991 ; 62: 2-4$

[57] Lekholm U, Zarb GA. Patient selection and preparation. In: Brånemark $\quad \mathrm{P}-\mathrm{I}, \quad$ Zarb $\mathrm{G}, \quad$ Albrektsson $\mathrm{T}$ (eds). Tissue-Integrated Prostheses: Osseointegration in Clinical Dentistry. Chicago: Quintessence 1985:202-208.

[58] van Steenberghe D. Periodontal aspects of osseointegrated oral implants ad modum Brånemark. Dent Clin North Am $1988 ; 32: 355-370$.

[59] Sonick M, Abrahams J, Faiella RA. A comparison of the accuracy of periapical, panoramic, and computerized tomographic radiographs in locating the mandibular canal. Int J Oral Maxillofac Implants 1994; 9: 455-460.

[60] Sharawy M, Misch CE. Anatomy for dental implants In: Misch CE, ed. Contemporary Implant Dentistry, 2nd ed. St. Louis: The CV Mosby Company; 1999: 217-224

[61] Jalbout Z, Tabourian G. Glossary of Implant Dentistry, Upper Montclair, NJ: International Congress of Oral Implantologists; 2004: 16

[62] Dao TT, Mellor A. Sensory disturbances associated with implant surgery. Int J Prosthodont 1998; 11: 462-469

[63] Walton JN. Altered sensation associated with implants in the anterior mandible: A prospective study. J Prosthet Dent 2000; $83: 443-449$

[64] Bartling R, Freeman K, Kraut RA. The incidence of altered sensation of the mental nerve after mandibular implant placement. J Oral Maxillofac Surg 1999; 57: 1408-1412. 